\title{
IAMJ
}

INTERNATIONAL AYURVEDIC MEDICAL JOURNAL

\section{CRITICAL ANALYSIS OF SHIMBHIDHANYAVARGA IN DIFFERENT RITUS \& DISEASES}

\section{$\underline{\text { Riyanka Kumari }}$}

PG Scholar, P.G. Department of Swasthavritta \& Yoga, R.G.G.P.G. Ay. College \& Hospital, Paprola, Kangra, H.P. (176115)

Corresponding Author: riyanka7691@gmail.com

https://doi.org/10.46607/iamj05p5032021

(Published online: March 2021)

Open Access

(C) International Ayurvedic Medical Journal, India 2021

Article Received: 24/02/2021 - Peer Reviewed: 03/03/2021 - Accepted for Publication: 04/03/2021

Check for updates

\begin{abstract}
Ayurveda the science of health always aimed to maintain health status of society. The good conduction of daily regimen not only maintains healthy lifestyle but also help to avoid medication for the treatment of diseases. To make the body healthy and strong, there are three sub pillars mentioned in Ayurveda. Ahara (food) is the basic need for an individual and an important tool in Ayurveda. Ahara acts as Aushadha (medicine). Shimbhi Dhanya Varga (Pulses) in daily diet plays an important role in maintaining muscle and bone strength. Health promotion can be done by pearl knowledge of Ayurveda, the science for the achievement of long, happy and healthy life. One among them is the varieties of pulses such as Mudga (green gram), Masha (Black gram), Adhaki (Red gram) and Makushtha (lentil), Rajashimbi (Soyabean), Satina (peas), etc. These three things help in balancing your Dosha. Diet means your food, and it is one of the most important things for our survival. The 12 groups mentioned by Charaka Samhita. Shimbhi Varga (pulses) is one of them. They are also called Vaidala (dicotyledons). Bhavamishra has also explained 23 vargas one of which is Dhanya varga. Dhanya varga is divided into five sub types which are as follows: 1. Shali Dhanya, 2. Vrihi Dhanya, 3. Shuka Dhanya, 4. Shimbi Dhanya, 5. Shudra Dhanya. Shimbhidhanya Varga (pulses) is rich in protein, calcium, phosphorus and magnesium. The pulses are main source of protein except non vegetarians. Also, for the promotion of health seasonal regimen is given prime importance in our Ayurvedic texts. Ahara when used in an appropriate way can be used as a medicine in various diseases. The main objective of this article is to understand the use of Shimbhidhanya Varga in different Ritus and
\end{abstract}


various diseases. An attempt has been made to explain the use of Shimbhidhanya Varga in different Ritus and diseases based on Ayurvedic and modern pharmacology.

Keywords: Shimbhidhanya, Ritus, Diseases

\section{INTRODUCTION}

Ayurveda the science of life is a time-tested treasure of knowledge that has been handed down to us from our great ancestors. The wisdom the foresight ness and pragmatic attitude structured in the classics aims for total positive health including physical, mental, spiritual well-being and combating with illness. For this total positive health Ayurveda has given three sub pillars- Ahara, Nidra and Brahmacharya, which support the body itself. Here Ahara, has been enumerated first, which shows its importance. Nature manages it earlier to create living being on the earth. Breast milk is the first and well-balanced food for the newly born baby. It is a well-known fact that, Ahara, supplies bioenergy to body. This bio energy is supplied by proper and adequate nutrition in the form of its essential constituent's viz. protein, carbohydrates, fats, minerals, vitamins and water. Through centuries food has been recognized as important for human being, in health and diseased state. Ayurveda, the science of life has not only emphasized on Ahara but also entire quality of it. Good nutrition means "maintaining a nutritional status that enables us to grow well and enjoy good health. Those who take proper diet live a long life and those not doing so die a premature death. Proper maintenance of the power of digestion is also depends upon the proper diet. It is true that research in current knowledge about nutrition have made great contribution in medical field by denoting the deficiency diseases and also in the treatment of diseases. Dietetics is the practical application of the principles of nutrition. It includes the planning of meal for both the normal and sick persons. Any aberration in diets and even in their preparation styles leads to ill health. It is well known fact from actual practices that the intake of proper diets is only means of survival. Thus, diets virtually constitute the varied life of living beings. The correlation of diets with life can be very well inferred from the actual experiences in the life. There are so many factors influencing on the diet and the methods of taking diet which reflect their effect on health. The main aim of Ayurveda is to maintain the health of the healthy person and to cure the illness of the diseased person.

Ayurveda is the one and only medical system which gives the way of perfect living with nature. It is a science which developed as a result of various discussions and researches. It gives equal importance to preventive and curative aspects of diseases. Ayurveda postulated the unique principles of Tridosha, Dhatu and Mala for the homeostasis of the body. Good health is the base of achievements like Dharma, Artha, Kama and Moksha. According to Ayurveda only physical, mental, social and spiritual well-being can be considered as Arogya (Health).

The food is said to be cause of stability for all living beings. There is nothing else except diet for sustaining the life of living beings. Ahara is said to be Mahabhaişajya by Kasyapacharya, hence no other medicament just like diet is not available. In other words, one is capable to make man disease free only with the cereals (congenial diet). One is not able to sustain life without diet even of endowed with medicine that is why the diet is said to be the great medicament by physician.

A self-controlled man blessed by noble man lives for hundred years free from diseases by the intake of wholesome food.

The articles of food, the taste, properties, potency, taste after digestion and actions of each one of them separately, which are prepared in the form of eatables, drinkables, likable and chewable, by the combination of many substances, adopting many processes and possessing different special effects; since physicians without such Conceptual, a knowledge will not be able to advise others on maintenance of health and 
prevention (of cure) of diseases, so all living beings are dependent on food.

Diet means our food, and it is one of the most important things for our survival. The 12 groups mentioned by Charaka. Shimbhivarga (pulses) is one of varga among these. They are also called Vaidala (dicotyledons). Shimbhi Dhanyavarga (pulses) is rich in protein, calcium, phosphorus and magnesium. The pulses are main source of protein except non vegetarians. Pulses comprise a variety of grams, also known as Dhals. Most commonly eaten pulses are Bengal gram (Chana), red gram (Urd). Others include lentils (Masur), peas and beans including Soyabean. Pulses contain 20 to 25 per cent of proteins, which is double that found wheat and three times that found in rice. In fact, pulses contain more protein than eggs, fish or flesh foods. But in regard to equality, pulse proteins are inferior to animal proteins. Although pulses are called "poor man's meat", they are eaten by the rich and poor alike in India. They give variety to the diet and make the food more palatable. If a patient intakes wholesome food, then there is no need of medicine and if a patient continuously consumes unwholesome food then also there is no need of medicine as medicine will not be effective. Pathya is defined as the Ahara (diet) which is congenial to a person according to his constitution, appetite and digestive capacity of the body. Public policies should put more emphasis on creating healthy food, built, and social environment to support and promote healthy diet and lifestyle.

\section{Aim and Objectives-}

1. To establish classical use of Shimbhidhanya Varga Dravya in various Ritus and diseases.

2. To study pharmacological properties of Shimbhidhanya Dravya.

\section{Materials and Methods-}

- All Ayurvedic literature (Brihatrayee, Laghutrayee, Nighantu etc.) With their commentaries.

- Supportive texts of contemporary science.

Table 1: Classification of Ahara According to Various Classics

\begin{tabular}{|c|c|c|c|}
\hline \multirow[t]{2}{*}{ S.No. } & \multirow[t]{2}{*}{ Charka } & \multicolumn{2}{|l|}{ Sushruta } \\
\hline & & Drava varga & Annapanavarga \\
\hline 01 & Sukadhanya & Jala & Dhanya \\
\hline 02 & Samidhanya & Ksira & Mamsa \\
\hline 03 & Mamsa & Dadhi & Phala \\
\hline 04 & Harita & Takra & Saka \\
\hline 05 & Phala & Ghita & Lavana \\
\hline 06 & Saka & Taila & Bhaksya \\
\hline 07 & Madya & Madhu & Anupana \\
\hline 08 & Ambu & $I k s h u$ & $\ldots \ldots \ldots \ldots$ \\
\hline 09 & Gorasa & Madya & ............ \\
\hline 10 & Ikshuvikara & Mutra & ........... \\
\hline 11 & Krtanna & $\ldots \ldots \ldots \ldots$ & ............ \\
\hline 12 & Aharayogi & $\ldots \ldots \ldots \ldots$ & $\ldots \ldots \ldots \ldots \ldots$ \\
\hline
\end{tabular}

Table 2: Classification according to Acharya Vagbhatta

\begin{tabular}{|l|l|l|l|}
\hline Astanga Sangraha & \multicolumn{2}{|l|}{ Atanga Hridaya } \\
\hline Panam & Annam & Dravam & Adravam \\
\hline Toyam & Sukadhanyam & Toyam & Sukadhanyam \\
\hline Ksiram & Simbidhanyam & Ksiram & Simbidhanyam \\
\hline Iksu & Pakvannam & Ikshu & Pakvannam \\
\hline Taila & Mamsam & Tailum & Mamsam \\
\hline Madyam & Sakam & Madyam & Sakam \\
\hline Mutram & Phalam & Mutram & Phalam \\
\hline & & & Ausadhavarga \\
\hline
\end{tabular}




\section{Concept of Ritu}

In Ayurvedic texts, a year is divided into two Ayana, depending on the direction of movement of sun that is Uttarayana (northern solstice) and Dakshinayana (southern solstice). Each Ayana comprises of three seasons which gives total of 6 seasons in a year. Each season lasts for two months. These six seasons are Shishira (winter), Vasanta (spring), Greeshma (summer), Varsha (monsoon), Sharada (autumn), and Hemanta (late autumn).

\section{Uttarayana and its effect}

Uttarayana indicates the ascent of the sun or northward movement of sun. In this period the sun and the wind are powerful. The sun takes away the strength of people and the cooling quality of the earth. It brings increase in the Tikta (bitter), Kashaya (astringent), and Katu (pungent) Rasa respectively, which brings about dryness in the body and reduces the Bala (strength). It is also called as AadanaKala.

\section{Dakshinayana and its effect}

Dakshinayana indicates the descent of the sun or movement of the sun in the southern direction. In this period, the wind is not very dry, the moon is more powerful than sun. The environment becomes cool due to the clouds, rain, and cold winds. Unctuousness sets in the atmosphere and Amla (sour), Lavana (salty) and Madhura (sweet) Rasa are predominant, so the strength of person enhances during this period. It is also called as VisargaKala.

Table 3: Ahara Dravya to be used in different seasons-

\begin{tabular}{|l|l|l|}
\hline Ritu & Kala & Aharadravya to be used \\
\hline Shishira & Aadana & $\begin{array}{l}\text { Madhur, Amla, Lavana Rasa } \\
\text { And SnigdhaGuna dominant Ahara is to be taken. }\end{array}$ \\
\hline Vasanta & Aadana & AharaKatu, Tikta and Kashaya in Rasa, Laghu and Ruksha in Guna, Ushna in Veerya is advised. \\
\hline Greeshma & Aadana & Ahara which is light to digest and have Madhura, Snigdha, Sheeta and Dravya Gunaia advised \\
\hline Varsha & Visarga & Ahara having Amla, LavanaRasa and of Snigdha, LaghuGuna is to be taken. \\
\hline Sharada & Visarga & AharaDravya having Madhura, Shaya and Tikta taste, and of Laghu and Sheeta Guna are advised. \\
\hline Hemanta & Visarga & Madhura, Amla, LavanaRasa and SnigdhaGuna Dominant Ahara is to be taken. \\
\hline
\end{tabular}

\section{Shambidhanyavarga in different seasons}

Ritucharya is prominently discussed in the first few chapters of most of the samhitas of Ayurveda. Prevention of disease to maintain health is being the first and foremost aim of the holistic science of Ayurveda. In Tasyashitya chapter of Charak Samhita, it is said "Tasyashitadiya Ahaarbalam Varnascha Vardhate. Tasyartusatmayam Vaditam Chestaharvyapasrayam," which means "the strength and complexion of the person knowing the suitable diet and regimen for every season and practicing accordingly are enhanced. Main theme of this chapter is to make people aware concerning the methods to live in accordance with the environment. In this article, the Ritucharyas mentioned in the classics of Ayurveda have been discussed and emphasis has been given on the likely impact of Ritucharya on lifestyle disorders. Hemanta Ritu
Mid November to mid-January is considered as $\mathrm{He}$ manta Ritu. Blow of cold winds starts, and chillness is felt. Predominant Rasa during this season is Madhura and the predominant Mahabhutas are prithvi and Apa. The strength of a person remains on highest grade and vitiated Pitta Doshas gets pacified. Activity of Agni in increased. One should use unctuous, sweet, sour, and salty foods. E.g. Mash

\section{ShishiraRitu}

Mid-January to mid-March (approximately) is considered as Shishira Ritu (winter). During this season, the environment remains cold, along with cold wind. The predominant Rasa and Mhabhuta during this season are Tikta (bitter) and Akasha, respectively. The strength of the person becomes less, deposition of Kapha Dosha occurs and Agni (catabolism) remains in a higher state. Food having Amla(sour) as the predominant taste are preferred.

Vasanta Ritu 
The approximate time is from mid-March to midMay. This season is considered as season of flowering and origin of new leaves. Predominant Rasa and $\mathrm{Ma}$ habhuta during this season are Kashaya (astringent), and prithvi and Vayu, respectively. Strength of the person remains in medium degree, vitiation of Kapha Dosha occurs and Agni remains in Manda state. One should take easily digestible foods. Among lentil, Mudga can be taken. Food items tasting Tikta (bitter), Katu (pungent), and Kashaya (astringent) are to be taken.

\section{Greeshma Ritu}

Mid-May to mild-July (approximately) is considered as Greeshma (summer) season. Environment is prevalent with intense heat and unhealthy wind. The predominant Rasa is Katu and Mahabhuta are Agni and Vayu. The Strength of the person become less, Deposition of VataDoshas occurs, but the vitiated KaphaDoshaa is pacified during this season.Agni of the person will remain in mild state. Foods which are light to digest-those having Madhura (sweet), Snigdha (unctuous), Sheeta (cold), and Drava (liquid) Guna, such as lentil, Mudga Yusha etc are to be taken.

Varsha Ritu
Mid July to mid-September (approximate) is considered as Varsha Ritu. During this season the sky is covered by clouds and rains occurs without thunderstorm. The predominant Rasa and Mahabhuta during this season are Amla and Prithvi and Agni, respectively. The strength of the person again becomes less vitiation of VataDoshas and deposition of PittaDoshas, Agni also gets vitiated. Foods having Amla and Lavan $a$ taste and of Sneha qualities are to be taken. E.g. MudgaYusha, Chanaka, Yusha

Sharad Ritu

The period between mid-September to mid November is Sharad Ritu (autumn). During this name the sun becomes bright, the sky remains clear and sometimes with white cloud, and the earth is covered with wet mud. predominant Rasa is Lavana (salty) and predominant Mahabhutas are Apa and Agni. The strength of the person remains medium, pacification of vitiated Vata Dosha and vitiation of Pitta Dosha occur, and activity of Agni increases during this season. Foods are having Madhura (sweet) and Tikta (bitter) taste, and of Laghu (light of digest) and cold properties are advised. Food having the properties of pacify vitiated Pitta are advised. E.g. Mudga Yusha, Chanaka Yusha

Table 4: Rasa, Guna, Veerya, Vipaka, Dosha Karma and Dhatu Karmaof Shimbhidhanya Varga

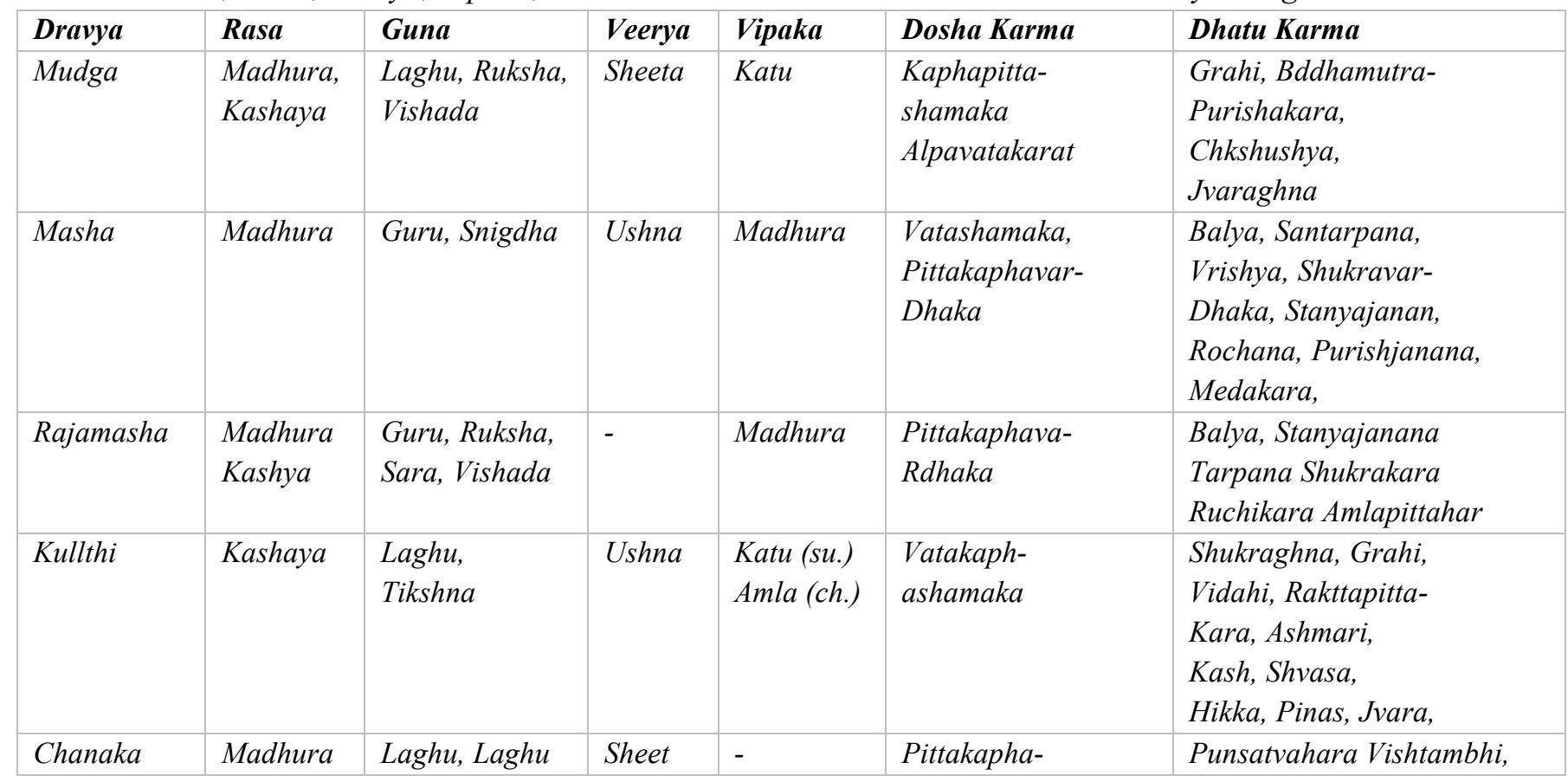




\begin{tabular}{|c|c|c|c|c|c|c|}
\hline & Kashaya & & & & $\begin{array}{l}\text { Shamaka } \\
\text { Vatavardhaka } \\
\text { Ghritayuktta, } \\
\text { Tridoshashamaka }\end{array}$ & $\begin{array}{l}\text { Virukshana, Jvaraghna, } \\
\text { Rakttapittahara }\end{array}$ \\
\hline Adhki & Madhura & $\begin{array}{l}\text { Laghu } \\
\text { Ruksha }\end{array}$ & Sheet & - & $\begin{array}{l}\text { Pittakaph-ashamka, } \\
\text { Vatavardhaka }\end{array}$ & Varnya, Grahi \\
\hline Makushthka & Madhura & $\begin{array}{l}\text { Laghu } \\
\text { Ruksha }\end{array}$ & Sheet & Madhura & $\begin{array}{l}\text { Pittakapha- } \\
\text { Shamaka, } \\
\text { Vatavardhaka }\end{array}$ & $\begin{array}{l}\text { Grahi, Krimikar Jvarghna } \\
\text { Rakttapitta- Hara }\end{array}$ \\
\hline Tila & $\begin{array}{l}\text { Madhura } \\
\text { Kashaya } \\
\text { Katu }\end{array}$ & $\begin{array}{l}\text { Guru } \\
\text { Snigdha }\end{array}$ & Ushna & Madhura & Kaphapittakara. & $\begin{array}{l}\text { Tvachya, Sheetsparsha, } \\
\text { Keshya, Medhakrut, } \\
\text { Agnikrut }\end{array}$ \\
\hline Masura & Madhura & $\begin{array}{l}\text { Laghu } \\
\text { Ruksha }\end{array}$ & Sheet & Madhura & $\begin{array}{l}\text { Pittakaphash- } \\
\text { amaka } \\
\text { Vtavardhaka }\end{array}$ & $\begin{array}{l}\text { Grahi Bddhamala-Kara, Jva- } \\
\text { raghna Rakttapitt- } \\
\text { Ahara }\end{array}$ \\
\hline Matara & Madhura & Ruksha & Sheet & Madhura & Vatavardhaka & $\begin{array}{l}\text { Vibandhakara Rakttapitt- } \\
\text { Ahara }\end{array}$ \\
\hline Soyabina & $\begin{array}{l}\text { Madhura } \\
\text { Kashaya }\end{array}$ & $\begin{array}{l}\text { Guru } \\
\text { Snigdha }\end{array}$ & Ushna & - & Vatashamaka & $\begin{array}{l}\text { Balya } \\
\text { Stanyajanana Durjara }\end{array}$ \\
\hline
\end{tabular}

Table 5: Shimbhidhanya Varga in various disease on the basis of chemical constituents present

\begin{tabular}{|c|c|c|}
\hline Diseases & Aahara Dravya & Chemical constituents present \\
\hline Piles & Masha & Phosphoric acid, protein, carbohydrate \\
\hline Fever & Makushthka, & $\begin{array}{l}\text { Protein, carbohydrate, Sneha, Resha, Phosphorus, vitamin A\&B1, } \\
\text { Khatik }\end{array}$ \\
\hline Worm infestations & Rajamasha & Protein, carbohydrate \\
\hline Respiratory system & Tila & Calcium, phosphorus, protein, carbohydrate \\
\hline
\end{tabular}

Table 6: Mineral and trace elements Contents of different pulses: - (All values are mg, per 100 gm of eligible portion)

\begin{tabular}{|l|l|l|l|l|l|l|l|l|l|}
\hline & $\begin{array}{l}\text { Energy } \\
\text { (Kcal) }\end{array}$ & $\begin{array}{l}\text { Protein } \\
\text { Pulses }\end{array}$ & $\begin{array}{l}\text { Fat } \\
\mathrm{g}\end{array}$ & $\begin{array}{l}\text { Calcium } \\
\mathrm{Mg}\end{array}$ & $\begin{array}{l}\text { Iron } \\
\mathrm{mg}\end{array}$ & $\begin{array}{l}\text { Thiamine } \\
\mathrm{Mg}\end{array}$ & $\begin{array}{l}\text { Riboflavin } \\
\mathrm{Mg}\end{array}$ & $\begin{array}{l}\text { Niacin } \\
\mathrm{mg}\end{array}$ & $\begin{array}{l}\text { Vit C } \\
\mathrm{mg}\end{array}$ \\
\hline Green Grma & 348 & 24.5 & 1.2 & 75 & 3.9 & 0.47 & 0.21 & 2.4 & 0 \\
\hline Red Gram & 335 & 22.3 & 1.7 & 73 & 2.7 & 0.45 & 0.19 & 2.9 & 0 \\
\hline Bengal Gram & 360 & 17.1 & 5.3 & 202 & 4.6 & 0.30 & 0.15 & 2.9 & 3 \\
\hline Horse gram & 321 & 22.0 & 0.5 & 287 & 6.77 & 0.42 & 0.2 & 1.5 & 1 \\
\hline Black Gram & 347 & 24.0 & 1.4 & 154 & 3.8 & 0.42 & 0.20 & 2.0 & 0 \\
\hline Peas dry & 315 & 19.7 & 1.1 & 75 & 7.05 & 0.47 & 0.19 & 3.4 & 0 \\
\hline Soyabean & 432 & 43.2 & 19.5 & 240 & 10.4 & 0.73 & 0.39 & 3.2 & 0 \\
\hline Horse Gram & 321 & 22.0 & 0.5 & 287 & 6.77 & 0.42 & 0.2 & 1.5 & 1 \\
\hline
\end{tabular}

\section{Shimbidhanya in diseases}

\section{Mudga (Green gram/Vigna radiata Linn.)}

The word Mudga in Sanskrit means "that which brings joy, delight and gladness". According to Acharyas, Mudga is Madura (sweet), Kashaya (astringent) in Rasa (taste), Laghu, Ruksha (dry), Shit- virya, KatuVipaka and it exhibits Kaphapittashamka Vatakarat property. Mudga is best in lentils. There are $347 \mathrm{kcal}$ energy in 100 grams Mudga. It is store house of calcium, potassium, iron, vitamins fat, carbohydrate etc. Mudga dal is rich in iron $(3.9 \mathrm{mg} / 100 \mathrm{gm})$ and potassium $(1246 \mathrm{mg} / 100 \mathrm{gm})$. Though iron is typically 
linked to haemoglobin-the protein that transports oxygen around the body-it is also vital for energy production, antioxidant défense. Potassium is one of the most important minerals in the body. It helps regulate fluid balance and reduce blood pressure. So, Mudga is important for hypertensive and osteoporosis individuals. Mudga soup can be given in UdaraRoga and Jvara.

\section{Masha (Black gram/Vigna mungo Linn.)}

Masha is Madhura in taste, Ushna Virya, Snigdha (unctuous), Balya Vardhaka (increase strength), Vatanashaka (mitigate Vata), Guru (hot in potency) Shukra Vriddhikara, Malakara, Virekakrit (increase semen and promotes ejaculation strength). Masha is known as Urad dal in Hindi. Black gram is mainly grown in south Asia. It produces bulk of faeces. Black gram or Urad dal holds a high protein value than most of the legumes. It is also an excellent source of dietary fiber, isoflavones, vitamin Bcomplex, iron, copper, calcium, magnesium, zinc, potassium, phosphorus which offers a myriad of healing health benefits. Urad dal is in fact, the only pulse that has more than 10 times of phosphorous than any other pulse and the unique type of protein present in black grams strengthen muscle fibres. Adding black gram to your daily diet adds bulk to the stool, eases bowel movement. It helps in treating constipation, colic and haemorrhoids and improves liver functions. Black gram is one of the top aphrodisiac foods and it not only increases sperm count and motility but also prevents impotency and premature ejaculation. In females, consuming Urad dal dishes during menstruation reduces abdominal and muscle cramps or dysmenorrhea. It also addresses the problem of scanty period and regularizes the menstrual cycle. It is high on potassium food and prevents the constriction of blood vessels and controls high blood pressure. It is rich iron content helps in the increase of red blood cells, thus facilitating the supply of oxygen throughout the body. Furthermore beans, lentils and dals are essential components of the DASH diet that helps in controlling high blood pressure. High fiber foods are often recommended to diabetics as it helps by regulating the amount of nutrients that's absorbed by the digestive tract. As a result, it can help you maintain your blood sugar and glucose levels, making your diabetes much more manageable. It prevents dramatic drops and spikes in the sugar levels as well.

\section{Rajamasha (Vigna unguiculate)}

Rajamasha is Madhura and Kashya in taste. It is considered dry, heavy, one that vitiates VataDoshas and is a potent laxative. It increases appetite and alleviates Kapha Doshas and Amalpitta. It is a diuretic and maintains proper digestion, is a diuretic and maintains proper digestion. Bhavamishra has mentioned three kinds of Rajamasha, white, red and black. He has described it as highly nutritious, capable of increasing milk production and that the larger beans are more suitable for consumption than the smaller variety.

\section{Kultthi (Dolichosbiflours Linn.)}

Kulattha is Kashaya in taste, Ushnavirya, Amlapaka (sour at the end digestion). Its Vatanashaka and Kaphashukrahar (reduces semen and vitiated Kapha). It is useful for Shurashmari (urinary stone) and constipation. According to Acharya Sushruta, VanyaKulattha which pacifies the deranged Kapha and proves curative in cases of Anaha, obesity, piles, hiccough, asthma and dyspnoea. Acharya Vagbhata described that this pulse increases bleeding disorders (like: pile). Horse gram seeds contain $21 \%$ of crude protein, $11 \%$ of pentosan. They also contain traces of urease and phosphorus.

\section{Chanaka (cicerareietinum Linn.)}

Chanaka is Madhura and Kshaya in taste, sheetvirya, MadhuraVipaka. Chanaka is Laghu, Ruksha (dry), Vatavardhaka in property. Bengal gram is full of fiber $(17 \mathrm{gm} / 100 \mathrm{gm})$ which helps to control blood sugar levels. It has cholesterol level $0 \mathrm{mg}$, so it helps in preventing heart problems.

\section{Adhaki (red gram/ Cajanuscajan Linn.)}

Adhaki is Laghu, Ruksha, Kashaya Madura, shita varna grahi and Kaphapitta Shamaka but Vatakara. Acharya Sushrura states that the Adhaki does not excessively agitate the Vayu in the organism. Apart from fiber (15 gm/100gm) and protein, it contains folic acid which helps to prevent anemia people and is helpful for pregnant women as it is necessary for foetal development and can prevent neural tube birth defects such as spina bifida. It is beneficial for obesity because it is 
low in calories $(335 \mathrm{kcal} / 100 \mathrm{gm})$. Adhakiyusha us useful in Pittaastisara.

\section{Makushthka (Cyperusrotudus/Moth)}

According to Acharya Charaka Makushthka is Madhura in Rasa, Sheetvirya, Vipak Madhura, Ruksha, Sangrahi, Ruksha. In Sushruta described that Makushthka is Krimikara, but according to Acharya Charaka it is beneficial in Raktapitta, Jvara, Atisara, Yakshma. Acharya Sushruta states that it is as alleviator of Pitta and Kapha. It is best TridoshaShamana.

\section{Tila (Sesamum indicum Linn.)}

Tila in ShimbhidhanyaVarga described by Acharya Charaka has Madhura in Rasa, Kshayaorkatu in Anurasa, Madhura Vipaka, Tvachya, sheetasparsha, Keshya, Balavardhaka, Guru, Snigdh, Alpamutra Ushna (hot in potency), Medhakrit, Agnikrit and Kaphapittakara.

The Khandika (Khesari) is known as Lathrus sativus is Ruksha, Madhura, Tikta, Kashya, Shita, Vatavardhaka, Kaphapittahara and Vibandhkara. It leads to development of lathyrus.

\section{Result}

Ahara Dravya mentioned in Shimbhidhanya Varga possess different pharmacological properties based on which one can use these in different seasons according to the seasonal changes in the body to maintain health in an individual. If one is not having food according to seasonal changes, this will lead to diseased condition due to disturbed metabolism (Agni) and decreased immunity (Bala). In that case also, one can use Ahara as medicine to treat various disease. So, one can also use Ahara Dravya described in Shimbhidhanya Varga based on the pharmacological properties in various disease.

\section{DISCUSSION}

Ingredient of Shimbhidhanya Varga is most important content of Ahara so they are mentioned at first classification. Shimbhidhanya means pulses/legumes. It is based on the season in which they grow. All have explained that species have different names in different region. Some species are not found nowadays. Shimbhidhanya which we use at present and mentioned in Samhita are-Mudga, Masur, Chanak and
Makushthaka. Shimbhidhanya Varga is also known as Shami Varga, Vaidala Dhanya and Supayoni. In general, all species have Madhura Kashaya Rasa and Sheet Veerya. They cause Vataprakopa in Koshtha. Different types of food were prepared. They were mainly- Peya, Vilepi, Manda, Odan, Krushara, Godhumika, Dhana and Pruthuka etc. thus main ingredient was rice with Shimbhi. They should be taken by person having good strength and only after processing with Ghee. In presence of Sneha, bio availability of proteins increases. Mudga and Masha are mentioned as best and worst amongst this class respectively. Even there is not much difference in nutritional values. So, it can be concluded that Mudga is mentioned as best because of bio availability of proteins and also it does less Vata Prakopa as compared to others. The food is said to be cause of stability for all living beings. There is nothing else except diet for sustaining the life of living beings. Ahara is said to be Mahabhaisajya by Acharya Kashyap. In other words, one is capable to make man disease free only with the food. Shimbidhanya Varga are available in different seasons (Ritus). However, based on the pharmacology mentioned in Ayurvedic texts they are sometimes not useful in the season in which they are available. So, here Dravya can be conserved or their dried forms can be used in the seasons in which they maintain and promote health due to pharmacological properties present in them. Improper diet leads to the diseased condition to varying seasons. So, Ahara Dravya mentioned in Shimbidhanya Varga may be used in various seasons and diseases like Diabetes Mellitus, hypertension and obesity based on pharmacology described in Ayurvedic and modern texts.

\section{CONCLUSION}

The pulses should be consumed daily in the form of diet for health promotion and disease prevention. Even Acharya Charka emphasizes on the daily intake of green gram and other pulses for maintenance of health along with Shuka Dhanyas, Phala and Shaka Varga. The pulses help in body building, stimulation of immune system, regulation of lipid and hormone metabolism and detoxication of enzymes. Shimbi- 
dhanya Varga are beneficial in variety of disease like Diabetes mellitus, hypertension, obesity etc.

\section{REFERENCES}

1. Raja Radhakantadev.Shabdakalpadruma, $3^{\text {rd }}$ Vol, Delhi, Nagar Publisher:1967

2. Vadavjitrikamji Acharya, Agniveshkarita Charaka Samhita Chakrapani Tika, Sutrasthana 27/23 Varansi: Chaukhamba Orientalia:2011

3. Vadavjitrikamji Acharya, Agniveshkarita Charaka Samhita, Sutrasthana 6 Varansi: Chaukhamba Orientalia Edition: Reprint 2007, Pg No.92.

4. Vadavjitrikamji Acharya, Agniveshkarita Charaka Samhita, Sutrasthana 27 Varansi: Chaukhamba Orientalia Edition: Reprint 2007, Pg. No. 371-373

5. Panditbhramashankara Mishra, Bhavprakashapurvadha Shimbhidhanyavaraga Chapter 4, Varanasi: Chaukhambha Bharati Academy:2005, $9^{\text {the }}$ dition

6. P.V. Sharma. Dravyaguna Vijnana. Varanasi Chowkambha Sanskrit Series Office:2000 $1^{\text {st }}$ Edition.

7. P.V. Sharma. Dravyaguna Vijnana. Varanasi Chowkambha Sanskrit Series Office:2000 2nd Edition, Pg No. 120

8. Vadavjitrikamji Acharya. Agniveshkarita Charaka Samhita Chakrapani Tika, Sutrasthana 25/79 Varansi: Chaukhamba Orientalia: Reprint 2011

9. Vadavjitrikamji Acharya. Agniveshkarita Charaka Samhita Chakrapani Tika, Sutrasthana 4/78 Varansi: Chaukhamba Orientalia: Reprint 2011

10. Vadavji Trikamji Acharya. Agniveshkarita Charaka Samhita Chakrapani Tika, Sutrasthana 3/189 Varansi: Chaukhamba Orientalia: Reprint 2011

11. Kavirajambikadutta Shastri A. M.S. With "Ayurveda Tattva-Sandipika" Sushruta Samhita Sutrasthana 45, Hindi Commentary Published by Chaukhambha Sanskrit Sansthana-Varansi. Part-1 Edition Reprint 2015.

12. Vadavji Trikamji Acharya. Agniveshkarita Charaka Samhita Chakrapani Tika, Sutrasthana 21/26 Varansi: Chaukhamba Orientalia, Edition:2011.

13. Kavirajambikadutta Shastri A. M.S. With "Ayurveda Tattva-Sandipika" Susruta Samhita Sutrasthana 46 Hindi Commentary Part-1 Published by Chaukhambha Sanskrit Sansthana-Varansi. Edition Reprint 2015, Pg No.244,274

14. Astangasangraha Of Vagbhata Edited with the 'Vidyotini' Hindi Commentary by Kaviraja Atrideva Gupta Chaukhambha Prakashan Sutrasthana 4 Pg No. 40

15. Astangasangraha Of Vagbhata Edited with the 'Vidyotini' Hindi Commentary By Kaviraja Atrideva Gupta Chaukhambha Prakashan Sutrasthana 4 Pg No. 41

16. Astangahrsangraha Of Vagbhata Edited with the 'Vidyotini' Hindi Commentary By Kaviraja Atrideva Gupta Chaukhambha Prakashan Sutrasthana 4 Pg No. 42
17. Astangasangraha Of Vagbhata Edited with the 'Vidyotini' Hindi Commentary By Kaviraja Atrideva Gupta Chaukhambha Prakashan Sutrasthana 4 Pg No. 4317.

18. Astangasangraha Of Vagbhata Edited with the 'Vidyotini' Hindi Commentary By Kaviraja Atrideva Gupta Chaukhambha Prakashan Sutrasthana 4 Pg No. 44

19. Astangahrdayam Of Vagbhata Edited with the 'Vidyotini' Hindi Commentary By Kaviraja Atrideva Gupta Chaukhambha Prakashan Sutrasthana 7 Pg No. 64

20. Astangahrdayam Of Vagbhata Edited with the 'Vidyotini' Hindi Commentary By Kaviraja Atrideva Gupta Chaukhambha Prakashan Sutrasthana 8 Pg No. 65

21. K Park-Park's Textbook Preventive and Social Medicine, Edition-24

22. Database on Medicinal Plants Used In Ayurveda-Vol 1 To 8, CCRAS Dept. Of Ayush, Ministry of Health And Welfare Govt. Of India, New Delhi. Reprint 2008 Pg No. 417

23. Ayurvedic Pharmacopoeia Of India, Part-1, Vol-4, First Edition, Pg No. 126

24. C.P. Khare Indian Medicinal Plants

Websites

https://medcraveoline.com

www.webmd.com

\section{Source of Support: Nil \\ Conflict of Interest: None Declared}

How to cite this URL: Riyanka Kumari et al: Critical Analysis Of Shimbhidhanyavarga In Different Ritus \& Diseases. International Ayurvedic Medical Journal \{online\} 2021 \{cited March, 2021\} Available from: http://www.iamj.in/posts/images/upload/2793 2801.pdf 